Composition and Cognition 
The University of California Press gratefully acknowledges publication support from the American Musicological Society.

The publisher and the University of California Press Foundation also gratefully acknowledge the generous support of the Constance and William Withey Endowment Fund in History and Music. 


\title{
Composition and Cognition
}

\author{
Reflections on Contemporary Music \\ and the Musical Mind
}

Fred Lerdahl

뚜 
University of California Press, one of the most distinguished university presses in the United States, enriches lives around the world by advancing scholarship in the humanities, social sciences, and natural sciences. Its activities are supported by the UC Press Foundation and by philanthropic contributions from individuals and institutions. For more information, visit www.ucpress.edu.

University of California Press

Oakland, California

(C) 2020 by Fred Lerdahl

Library of Congress Cataloging-in-Publication Data

Names: Lerdahl, Fred, 1943- author.

Title: Composition and cognition : reflections on contemporary music and the musical mind / Fred Lehdahl

Description: Oakland, California : University of California Press, [2020] | Includes bibliographical references and index.

Identifiers: LCCN 2019007500 (print) LCCN 20I9009894 (ebook) | ISBN 978052097325I (ebook) | ISBN 9780520305090 (cloth : alk. paper) | ISBN 9780520305 I06 (pbk. : alk. paper)

Subjects: LCSH: Music-Psychological aspects. Composition (Music) | Musical analysis. | Musical perception. | Music theory.

Classification: LCC ML3830 (ebook) | LCC ML383O.L367 2020 (print) | DDC 78r.I-dc23

LC record available at https://lccn.loc.gov/2019007500

Manufactured in the United States of America

$\begin{array}{llllllllll}29 & 28 & 27 & 26 & 25 & 24 & 23 & 22 & 21 & 20\end{array}$

I0 $\quad 9 \begin{array}{lllllllll} & 8 & 7 & 6 & 5 & 4 & 3 & 2 & \text { I }\end{array}$ 
For my wife, Louise Litterick 
